\title{
Association of body mass index and physical activity with the risk of developing type 2 diabetes mellitus in the next decade
}

\author{
Francisca Alexandra Araújo Da Silva*, Rosangela Gomes dos Santos, Leandro Araújo Carvalho, \\ Aline Mayra Lopes Silva, Ana Luísa Batista Santos, Thereza Maria Magalhães Moreira \\ From 20th Brazilian Diabetes Society Congress \\ Porto Alegre, Brazil. 11-18 November 2015
}

\section{Background}

The chronic noncommunicable diseases appear as the main causes of death and disability in the world. So, type 2 diabetes is one of the most significant and modifiable degrading situation for health.

\section{Objective}

To investigate the association of body mass index and physical activity with the risk of developing type 2 diabetes.

\section{Materials and methods}

This study was developed during health activities carried out by primary care to 183 city residents members of the interior of Brazilian Northeast. The risk of developing type 2 diabetes in the next 10 yrs. was obtained through the questionnaire Finnish Diabetes Risk Score. It was considered in overweight the users who had a body mass index equal or higher than 25.0, and physically active users who performed a minimum of $150 \mathrm{~min}$ of physical activity per week.

\section{Results}

It was found a significant association between body mass index $(\mathrm{p}<0.00)$ and physical activity $(\mathrm{p}<0.01)$ with the risk of developing type 2 diabetes in the next decade. There was a greater participation of women in the study (121; $66 \%)$. In comparison with male gender, female was more physically inactive $(105 ; 57.4 \%)$. It was founded a high risk of developing type 2 diabetes in the sample $(122,66.7 \%)$.

* Correspondence: falexandraaraujos@yahoo.com.br Universidade Estadual do Ceará, Fortaleza, Brazil

\section{Conclusions}

The results indicate that there may be interference between distribution of body mass as well as to the practice of physical activity and the risk of developing type 2 diabetes in the next 10 yrs.

Published: 11 November 2015

\section{doi:10.1186/1758-5996-7-S1-A155}

Cite this article as: Da Silva et al:: Association of body mass index and physical activity with the risk of developing type 2 diabetes mellitus in the next decade. Diabetology \& Metabolic Syndrome 2015 7(Suppl 1):A155.
Submit your next manuscript to BioMed Central and take full advantage of:

- Convenient online submission

- Thorough peer review

- No space constraints or color figure charges

- Immediate publication on acceptance

- Inclusion in PubMed, CAS, Scopus and Google Scholar

- Research which is freely available for redistribution
() Biomed Central 